\title{
Descenso a los inferos e iniciación. El exilio de Ciudad de México a La Habana de María Zambrano
}

\author{
Descent Into the Infernos and Initiation. \\ Maria Zambrano's Exile from México City to La Habana
}

Noelia Domínguez Romero

Universidad de Sevilla ndominguez@us.es

DOI: https://doi.org/10.15366/bp2020.25.006

Bajo Palabra. II Época. No25. Pgs: 129-152 


\section{Resumen}

El presente texto trata de recorrer, al unísono desde lo textual y lo vivencial, los primeros pasos del exilio político y filosófico de María Zambrano en América. La pensadora española, tras vivir unos meses de destierro en París, arribará en el fatídico 1939 a México, tierra que la abrazaría hasta su partida un año después hacia la mayor de las Antillas, Cuba, su Isla secreta, lugar de lo poético-sagrado y de encuentro con amistades verdaderas. En ese descenso a los ínferos su propia palabra, hecha de afectos, sueños y memoria, se volverá salvación.

Palabras clave: Zambrano, exilio, México, Cuba, inferos, iniciación, libertad, destino.

\section{Abstract}

This paper focuses on the first steps of María Zambrano's political and philosophical exile in America from both textual and experiential points of view. In the fateful year 1939, the Spanish thinker, after living a few months in exile in Paris, arrived in Mexico, a land that would embrace her until her departure a year later to the largest of the Antilles islands, Cuba, her secret Island, a place for the poetic-sacred and meeting with true friends. In that descent into the infernos, his own word, made of affections, dreams and memory, will become salvation.

Keywords: Zambrano, exile, Mexico, Cuba, infernos, initiation, liberty, fate. 
Entretanto no dejemos apagarse el fuego. Esa "ascua viva”. Sí, tienes razón, ¡tan poco! ¡Pero tan verdadero y luminoso! "Una lucecita...".

José Bergamín, en carta dirigida a María Zambrano. París, 6 de diciembre de $1957^{1}$.

Estas palabras, escritas por José Bergamín, en el exilio, bien vienen a revelar el espíritu esperanzador que definió a ambos amigos. El fuego - "ascua viva”, "lucecita"- que no ha de ser abandonado, frente a la experiencia ${ }^{2}$ que sufre el yo empírico cuando queda despojado de su lugar de origen, de sus raíces familiares y personales, podría aparecer, en el texto del poeta madrileño, como metáfora de un sentir originario, que, en el caso de Zambrano, se vuelve centro de su búsqueda vital y filosófica. Exactamente, en "Carta sobre el exilio", ensayo redactado por la autora en $1961^{3}$, se aprecia cómo el sufrimiento causado por tan abrumadora y angustiosa situación política y existencial le reveló la verdadera conciencia de sí; con este sacrificio ganó, matiza la investigadora Ana Bundgård, "la 'lucidez’ de un saber de iniciación que, a su juicio, fecunda la vida” ${ }^{4}$, un saber epistemológico y metafísico:

El exilio de la tierra propia, en situaciones excepcionales, como es el caso de María Zambrano, llega a ser experiencia de esclarecimiento y vía de conocimiento, pues, en esos casos, el sentimiento de abandono, el sufrimiento y el desarraigo del exiliado despiertan en él la aspiración a ser libertado del yo escindido en el tiempo y hacia la unión con el ser. María Zambrano asigna un alcance metafísico a esas vivencias que así quedan situadas en un nivel epistemológico 5 .

\footnotetext{
${ }^{1}$ Bergamín, J., Dolor y claridad de España. Cartas a María Zambrano, Sevilla, El Clavo Ardiendo. Editorial Renacimiento, 2004, p. 52. Los dos intelectuales se conocieron gracias a la revista espańola Cruz y Raya, dirigida por el propio José Bergamín, quien invitó a una joven María Zambrano a colaborar en el número 6 (septiembre de 1933), dedicado a la figura de su maestro, el filósofo madrileńo José Ortega y Gasset. Desde entonces nació una profunda y duradera amistad que estuvo marcada por una vida vuelta hacia la belleza y la nostalgia de lo propio, esencialmente tras el desastre de la guerra civil española y la experiencia mutua, compartida, del posterior exilio.

${ }^{2}$ Sobrecogedora, siempre trágica: "El exilio es algo curiosamente cautivador sobre lo que pensar, pero terrible de experimentar. Es la grieta imposible de cicatrizar impuesta entre el ser humano y su lugar natal, entre el yo y su verdadero hogar: nunca se puede superar su esencial tristeza. [...] Los logros del exiliado están minados siempre por la pérdida de algo que ha quedado atrás para siempre", Said, E. W., Reflexiones sobre el exilio, Barcelona, Debate, 2001, p. 179.

${ }^{3}$ Y publicado en Cuadernos del Congreso por la Libertad de la Cultura, n. 49, París.

${ }^{4}$ Bundgård, A., "Exilio y transcendencia", en Aurora. Papeles del "Seminario Maria Zambrano", Barcelona, n. 8 (2007), p. 87

5 Ibid., p. 85.
} 
Una vida, la suya, que ya no podía no quedar solapada a la historia y a la razón, tampoco a lo dictado por el corazón ${ }^{6}$ y las siempre ahí entrańas - símbolo "que capta $[. .$.$] lo originario, el sentir irreductible, primero del hombre en su vida, su$ condición de viviente"

En el exilio, con la nostalgia de lo perdido y el vértigo de la vida presente, se enfrentó Zambrano a un nuevo modo de pensar y de sentir, de hallarse en la historia y de ser en las circunstancias. Tratando de entender su tiempo, y con él la naturaleza de lo español ${ }^{8}$, no renunció a la condición creadora del alma humana; más bien, apostó desde el desarraigo por una razón conciliadora de la vida y del propio pensamiento: la razón poética, que será no sólo un método de trabajo, sino un modo de vivir y de estar en la existencia, que da acceso "a una realidad más profunda, una realidad en la que se integran el análisis del hombre, de sus relaciones con el otro y con lo divino en una síntesis armónica de metafísica y mística, de poesía e historia, de forma y sueño, o de delirio o destino" 9 .

\section{Sólo México nos abrazó}

La América hispana fue el lugar elegido por la mayoría de los exiliados ${ }^{10}$ espańoles del año treinta y nueve. Los intelectuales, como consecuencia de la guerra civil española, miraron esta tierra como el lugar sorteado para empezar una nueva

\footnotetext{
${ }^{6}$ Por lo vivido y desde lo vivido el corazón se convertirá, para Zambrano, en el órgano principal de su pensamiento, tal y como nos va anunciando a través de sus escritos, y desvelando y configurando con su razón poética. Imprescindibles son, a este respecto, los siguientes textos: "La metáfora del corazón (fragmento)" (Orígenes, La Habana, 1941) y "Las dos metáforas del conocimiento" (La Verónica, La Habana, 1942). Por otro lado, para conocer los tres momentos que recorre la metáfora del corazón en la obra zambraniana, véase el estudio realizado por la profesora mexicana Mariana Bernárdez: "La metáfora del corazón”, en Rivara, G. y Lizaola, J. (eds.), Exilio y razón poética. María Zambrano en el centenario de su nacimiento, México D.F., Cátedras. Universidad Nacional Autónoma de México, 2009, pp. 133-149.

7 Zambrano, M., El hombre y lo divino, Madrid, Fondo de Cultura Económica, 2005, pp. 177-178.

${ }^{8} \mathrm{Y}$ de acuerdo con Ana Bundgård: "El proyecto zambraniano es, en primer lugar, definir a España no históricamente, sino como una esencia con estatuto ontológico, y, en segundo lugar, determinar cuáles son las características del sustrato originario y oculto del alma humana", Bundgård, A., "El binomio España-Europa en el pensamiento de Zambrano, Ferrater Mora y Ortega y Gasset", en Revilla, C. (coord.), Claves de la Razón Poética. María Zambrano: un pensamiento en el orden del tiempo, Madrid, Trotta, 1998, p. 48.

9 Tirado Rozúa, J. R., "La razón poética ante la democracia", en Actas del II Congreso Internacional sobre la vida y obra de María Zambrano, Fundación María Zambrano, Vélez-Málaga, v. I (1998), p. 786.

${ }^{10} \mathrm{O}$ transterrados. José Luis Abellán, comentando el texto de José Gaos "Los 'transterrados' españoles de la filosofía en México", sugiere que el asturiano "ha expresado esta vivencia [sentir la nueva tierra no como absolutamente extrańa] diciendo que los espańoles en el Nuevo Mundo no se sentían 'desterrados', sino 'transterrados', pues su nueva vida se experimenta como una prolongación de la anterior" (El exilio filosófico en América. Los transterrados de 1939, Madrid, Fondo de Cultura Económica, 1998, p. 28). Se emplea aquí con el mismo sentido.
} 
vida ${ }^{11}$. Algunos formaban parte, desde el ańo 1936, de la llamada Escuela de Madrid, como José Gaos y María Zambrano, y otros, de la de Barcelona, como Eduardo Nicol, Joaquín Xirau, Juan David García Bacca y José Ferrater Mora, y Eugenio Ímaz, de una posible escuela donostiarra ${ }^{12}$. América les ofrecía, además de asilo lingüístico, refugio cultural -compartían un pasado-y político - países como Argentina, Uruguay, Perú, Venezuela, Cuba, Puerto Rico, y México especialmente $^{13}$, les abrieron sus puertas-. Este último se caracterizó por su generosa acogida; el contacto fue cercano, familiar, y esa grata impresión acompañó a los recién llegados.

El 28 de enero de 1939, exactamente, María Zambrano cruzó la frontera española camino de Francia - era el inicio de su largo exilio, el cual duraría más de cuarenta años-, constituyendo, con centenares de españoles, uno de los éxodos más trágicos de la historia de Espańa y de Europa. Allí la filósofa se encontró con su marido, el historiador Alfonso Rodríguez Aldave, y con su madre, su hermana Araceli y la pareja de ésta, Manuel Muñoz, quien pronto vería su vida truncada por otro horror, el nazismo. París fue, para ella y su familia, por poco tiempo, un trozo de luz en medio de tanta oscuridad. Sin embargo, el destino de Zambrano no se encontraba ahí, sino en América, continente que pisó por primera vez en 1936, acompañando a Rodríguez Aldave -recién nombrado secretario de la Embajada Española- a Santiago de Chile ${ }^{14}$; viaje que apenas duró seis meses, viéndose inte-

11 José Gaos, en el texto anteriormente citado, hablará de una "singular fidelidad" para con la vida nueva por parte de los exiliados españoles de 1939: “Toda emigración representa una experiencia vital tan importante como no puede menos de ser la de emprender una vida más o menos nueva. Pero una emigración forzosa representa la experiencia de emprender una vida más o menos nueva en una peculiar relación con la vida anterior. Como ésta se dejó por fuerza y no por prever otra vida preferible y resolverse a vivirla, se vive la vida nueva con una singular fidelidad, entre efectivamente espontánea y moralmente debida, a la anterior, lo que da de sí una potenciación de lo que retenía en ésta, lo valioso de ella, menos notorio en lo habitual de la posesión que en lo al pronto insólito de la pérdida y en lo engrandecedor, que no empequeñecedor, de la distancia temporal en el recuerdo", Gaos, J., "Los 'transterrados' españoles de la filosofía en México", en Filosofía y Letras. Revista de la Universidad de México, n. 36 (octubre-diciembre 1949), p. 288.

12 En torno a la existencia de una escuela en Donostia: "No se ha hablado nunca de una escuela de pensadores vascos. Sin embargo, partiendo de la premisa de que ni la Escuela de Madrid ni tampoco la de Barcelona presentan características comunes (algunos historiadores de la filosofía incluso dudan de la existencia misma de estas escuelas) podemos suponer que una nueva corriente de pensamiento, con sucesivas ramificaciones en el exilio y en la cultura española de los años cuarenta y cincuenta, ha tenido origen en la ciudad de San Sebastián en torno a la figura del catedrático y sacerdote vasco Juan Zaragüeta”, Llera, L. de, Filosofía en el exilio: España redescubre América, Madrid, Ediciones Encuentro, 2004, pp. 61-62.

13 Para conocer las principales fuentes, los textos y manuales más relevantes, las bibliotecas especializadas, las asociaciones y las fundaciones sobre el exilio espańol del 39 en México, se recomienda consultar este artículo de Walter L. Bernecker: "Los estudios sobre el exilio republicano en México", en Pagni, A. (ed.), El exilio republicano español en México y Argentina. Historia cultural, instituciones literarias, medios, Bilbao, Iberoamericana. Vervuert. Bonilla Artigas Editores, 2011, pp. 33-57.

${ }^{14}$ Viajaron a bordo del Santa Rita e hicieron escala en La Habana, sin saber Zambrano lo que acabaría significando este lugar en su vida, en su corazón y en su intelecto, y las personas que allí encontró, años después. Especialmente, 
rrumpido por el estallido de la guerra civil y, en consecuencia, por el forzado regreso a España ${ }^{15}$. En ese agónico 1939, de nuevo, le era necesario cruzar el Atlántico, pero para renacer, para sentirse otra vez en la vida. Parece ser que, ayudada por su buen amigo el poeta León Felipe y por Narciso Bassols, entonces embajador de México en el país galo, pudo continuar su camino, junto a su esposo, y empezar a vislumbrar un futuro en Ciudad de México ${ }^{16}$, lugar que, más tardíamente, María Zambrano recordaría con estas carińosas y a la vez invectivas palabras:

Yo llegué a México invitada por la Casa de Espańa, que muy pronto se llamaría Colegio de México. Era un gesto realmente inusitado, ningún país nos quería a los refugiados españoles, sólo México, sólo México, no me cansaría de decirlo, como una oración. Sólo México nos abrazó, nos abrió camino. Yo fui privilegiada en eso, como en tantas cosas, invitada a la Casa de Espańa, al poco tiempo de ser inaugurada. Su fundador, Daniel Cosío Villegas, había ido a Valencia para ver qué personas podía llevarse a México. Yo estaba en Chile, pero me dejó su invitación a través del gran poeta y amigo, León Felipe.

Recuerdo cómo atravesé la frontera entre medio millón de españoles. Tengo que hacer un esfuerzo para olvidar esa imagen terrible en la memoria, esa memoria que es mediadora también, pero puede aplastarnos, devorarnos. Me veo después en tierras de México, tomando el tren en Veracruz, cruzando en el tren entre aquellos inmensos volcanes, entre aquellas violetas. Todo era inmenso. Recuerdo las violetas de Córdoba y un paisaje inmenso, dulce y tierno. Estaba también la presencia española con todas sus contradicciones. México ha debido de tener muchos mediadores, cada uno de ellos en su forma y en su estilo, también los españoles ${ }^{17}$.

en su primera y brevísima estancia en la capital cubana, en 1936, María Zambrano dictó una conferencia dedicada al pensamiento de su maestro José Ortega y Gasset en el Lyceum and Lawn Tennis Club y conoció al poeta José Lezama Lima y a otros miembros del grupo Orígenes. "Tras de una larga y azarosa travesía en un barco español, [...] llegamos a La Habana, en este buque que, según supimos después, iba a Veracruz. Mas al llegar a La Habana, bajo el poder del general Fulgencio Batista, el barco fue detenido, su tripulación encarcelada, y nosotros, solamente sustraídos a esta suerte por un pasaporte diplomático. Creo haberlo ya relatado, que prodigiosamente en un lugar llamado La Bodeguita del Medio, nos ofrecieron una cena unos cuantos intelectuales de izquierda, entre ellos, el muy joven e inédito José Lezama Lima, quien me sorprendió por su silencio y por referirse a lo poco que yo había publicado en la Revista de Occidente", Zambrano, María, "A modo de Prólogo", en Filosofía y poesía, México, Fondo de Cultura Económica, 1993, pp. 7-8. Prólogo fechado en Madrid, el 15 de febrero de 1987. Véanse los estudios que sobre esta estancia chilena de María Zambrano ha escrito y publicado la investigadora Pamela Soto: "Chile: un inolvidable y decisivo viaje”, en Moreno Sanz, J. y Muńoz Vitoria, F. (eds.), María Zambrano, 1904-1991. De la razón cívica a la razón poética, Madrid, Publicaciones de la Residencia de Estudiantes-Fundación María Zambrano, 2004, pp. 103109 y "María Zambrano en Chile", en Moreno Sanz, J. (ed.), María Zambrano. Ahora, ya, monográfico de la revista República de las letras, Madrid, n. 89 (2005), pp. 48-68.

15 Una vez en España, Zambrano se marchó con su marido a Valencia y al poco tiempo a Barcelona, donde fue miembro del Consejo de Propaganda y del Consejo Nacional de la Infancia Evacuada y colaboró activamente en las Misiones Pedagógicas. Mientras tanto Rodríguez Aldave se unió al ejército republicano.

${ }^{16}$ La pareja tomó un barco desde Cartagena a Nueva York y desde allí a La Habana, antes de llegar a su destino final: el puerto de Veracruz.

17 Zambrano, M., "Entre violetas y volcanes", en Las palabras del regreso, edición de Mercedes Gómez Blesa, Madrid, Cátedra, 2009, pp. 224-225. También puede encontrarse en las Obras Completas. VI (Escritos 
México, recuperado, si no total sí parcialmente, de las secuelas de la revolución, entró en una época política de cierta estabilidad, que le llevó a expandirse y a alcanzar grandes reformas sociales. El gobierno cardenista, simpatizador con las ideas de la Segunda República española, se solidarizó con los vencidos españoles acogiéndolos como hijos adoptivos de su nación ${ }^{18}$.

Además, el país tenía una situación filosófica muy adecuada para los intelectuales exiliados españoles ${ }^{19}$. Como sucedió en la Península, se atacó al positivismo, y, sobre todo, hubo una afanosa preocupación por la identidad filosófica y por la propia circunstancialidad, antes del resplandor orteguiano, con el Ariel de José Enrique Rodó en 1900 -marca, por otro lado, palpable en todo el continente-. En los albores del siglo xx, el pensamiento predominante en este país americano fue, a grandes rasgos, el que se relata a continuación ${ }^{20}$ : antes de 1910, persistían algunos flecos de la filosofía escolástica con vestigios del positivismo decimonónico de Comte, Spencer, Taine y Mill, que serían poco después superados dado el ataque recIbido de parte de los denominados "los fundadores”, entre ellos Antonio Caso y José Vasconcelos. El siglo xix se vio fracasado; frente al positivismo ${ }^{21}$, al cientificismo y a la razón 'física y abstracta' (que diría Ortega), se exaltó la intuición como auténtica fuente de conocimiento. Una vez fundada la Universidad Nacional e iniciada la Revolución mexicana empezó a cobrar valor el vitalismo de Bergson y Nietzsche, a la vez que se fueron pre-

autobiográficos 1928-1990), edición de Jesús Moreno Sanz, Barcelona, Galaxia Gutenberg, 2013, pp. 771-772.

${ }_{18}$ Pero México no dejaba de ser un país con escaso poder económico: "gran parte de los recursos financieros para esta inserción provino menos del gobierno de México que de las organizaciones generadas por el propio gobierno republicano a poco de concluir la guerra, primero del Servicio de Evacuación de Republicanos Españoles (SERE), con su Comité Técnico de Ayuda a los Republicanos Espańoles (CTARE), y luego de la Junta de Ayuda a los Republicanos Españoles (JARE). Estas instituciones socorrieron a la gran mayoría de los refugiados, financiaron gran parte de sus proyectos culturales y, por un tiempo, crearon en México fuentes de trabajo con los fondos que originalmente provinieron de la propia República ya en el exilio", Lida, C. E., "El exilio en vilo", en Pagni, A. (ed.), El exilio republicano español en México y Argentina. Historia cultural, instituciones literarias, medios, Bilbao, Iberoamericana. Vervuert. Bonilla Artigas Editores, 2011, pp. 21-22.

19 Aunque Octavio Paz se referirá a los poetas españoles exiliados, el destino fue compartido con sus compañeros, los filósofos: "El destierro de los poetas españoles puede verse como un episodio de la historia de la emigración republicana que, a su vez, fue una de las consecuencias de la guerra civil espańola que, a su vez, es un capítulo particularmente dramático de la historia de las guerras ideológicas del siglo XX", "México y los poetas del exilio español", en Hombres en su siglo, Barcelona, Seix Barral, 1984, pp. 49-50.

20 Sirva, a modo de orientación, esta referencia: Hurtado, G., "La filosofía en México en el siglo XX", en Garrido, M.; Orringer, N. R.; Valdés, L. de; Valdés, M. M. (coords.), El legado filosófico español e hispanoamericano del siglo XX, Manuel, Madrid, Cátedra, 2009, pp. 1159-1173.

${ }^{21}$ Véase de Leopoldo Zea -el reputado filósofo mexicano y reconocido discípulo de Gaos-El positivismo en México, México, El Colegio de México, 2 tomos, 1943-1944 (nueva edición en México, Fondo de Cultura Económica, 1975). 
sentando los cimientos de un pensar propio $^{22}$, pensar que no se negó a recibir influencias externas. Y entre el lapso de los años treinta a los cuarenta México se dejó seducir por la fenomenología de Husserl y el existencialismo heiddegeriano, difundidos por los ilustres filósofos espańoles a su venida tras la derrota republicana; muy acogidas fueron también las teorías de Ortega y Gasset y las ideas de Dilthey.

Y en este contexto filosófico y cultural se movió María Zambrano a su llegada a México, en el mes de marzo de 1939, donde fue invitada, por el historiador mexicano Daniel Cosío Villegas, a impartir unas conferencias - que serán el germen de su obra Pensamiento y poesía en la vida española (1939)_, como "miembro especial", en La Casa de España ${ }^{23}$, organismo, erigido en 1938, que apostó por el saber desde sus inicios, ayudando a intelectuales, tanto autóctonos como foráneos, a desplegar y ampliar sus trayectorias profesionales. En pocos años, $\mathrm{La}$ Casa, que recibió el nombre de El Colegio de México, impulsó la equidad entre investigadores mexicanos y españoles. La Sección de Filosofía, a cargo de José Gaos, fue muestra más que clara del esplendor que la filosofía española había empezado a tomar en ese difícil periodo histórico, cuyo eco resonó en toda Hispanoamérica. Simultáneamente, se crearon otras instituciones que hicieron posible una auténtica integración entre españoles y mexicanos: el Centro de Estudios Filosóficos, fundado en 1945; el Ateneo Español, en 1948; la creación en 1934 - de la mano de Cosío Villegas-de la editorial Fondo de Cultura Económica, que facilitó el descubrimiento y la consiguiente difusión del conocimiento en las naciones en lengua española. Igualmente, hay que destacar la importancia de algunas revistas académicas, como Cuadernos Americanos, que vio su luz en 1941, gracias al apoyo del poeta y ensayista espańol Juan Larrea. Todo ello dejaba entrever un joven y activo momento cultural y un ápice de la habida síntesis.

Pero a pesar de la gran acogida que tuvo María Zambrano a su llegada a Ciudad de México, y aun respaldada por la buena receptividad de su obra y su pensamiento, no fue integrada totalmente en La Casa de España, como había creído en un inicio,

\footnotetext{
22 Sobre este asunto: "A principios de los ańos veinte, diversos intelectuales hispanoamericanos cobraron conciencia de que Hispanoamérica había vivido desde la época de la Conquista un colonialismo cultural inaceptable. Con los ojos siempre vueltos hacia Europa habían cultivado siempre una filosofía prestada que había impedido el desarrollo de una genuina filosofía 'criolla' que partiera de reflexionar sobre los problemas de Hispanoamérica y su historia, y que de alguna manera se engarzara con tradiciones culturales propias. La preocupación por encontrar la propia identidad cultural se encuentra en la base de muchas obras producidas entre las décadas de los ańos veinte y los cincuenta", Valdés, M. M., "El pensamiento filosófico en Hispanoamérica en el siglo xx", en Garrido, M.; Orringer, N. R.; Valdés, L. M.; Valdés, M. M. (coords.), El legado filosófico español e hispanoamericano del siglo $X X$, op. cit., p. 1115.

23 Para una descripción más exhaustiva y pormenorizada sobre las actividades culturales que se desarrollaron durante este periodo en La Casa de España léase: Lida, C. E., La Casa de España en México, México, El Colegio de México, 1988.
} 
y, en consecuencia, la filósofa se vio obligada a sufrir un nuevo exilio dentro del exilio mexicano ${ }^{24}$. Esta vez su viaje se detuvo en la ciudad michoacana de Morelia, donde residió durante nueve meses y escribió dos de las obras fundamentales de su corpus filosófico: Pensamiento y poesía en la vida española ${ }^{25}$ y Filosofía y poesia ${ }^{26}$, además de un texto inédito, La crisis de la objetividad, y numerosos artículos y ensayos en revistas especializadas de América y Europa.

Abandonar Ciudad de México supuso dejar un lugar que empezaba a amar y también despedirse de sus amigos, especialmente, de los poetas León Felipe y

${ }^{24}$ Estudiosos de la obra zambraniana subrayan el siguiente infortunio como causa primera de su partida de Ciudad de México a Morelia: "Este éxito, sin embargo, y su derivada visibilidad, pudieron motivar esa especie de ajuste de cuentas desencadenado en el seno de aquel orteguismo expatriado liderado por José Gaos: sus antiguos compañeros y colegas fueron "obstáculo" — de acción y, sobre todo, de omisión- para su permanencia en Ciudad de México. A María Zambrano no le quedó más remedio que aceptar un mal contrato en una universidad secundaria de una ciudad de provincias. Morelia fue, en cierto modo, una suerte de destierro dentro del exilio. El primer acto de un camino de espinas que no había hecho más que empezar", Martín, F. J., "Habitar el exilio entre las ruinas de la historia”, en Zambrano, María, España. Pensamiento, poesía y una ciudad, op. cit., p. 42. Por su parte, también recientemente, los investigadores Beatriz Morán Gotari y Agustín Sánchez Andrés argumentan, sin negar la explicación del profesor Martín, que "no obstante, hay que tener en cuenta las dificultades que suponía acomodar al elevado número de filósofos espańoles que iban llegando a México en esos días, muchos de ellos con un prestigio académico bastante más consolidado que el de la joven Zambrano. En este sentido, sólo un pequeño grupo de los filósofos del exilio, entre los que se encontraban José Gaos, Joaquín Xirau y José Medina Echaverría, entre otros, lograron ingresar en La Casa de España. La mayoría debió integrarse en otras instituciones mexicanas [...]", "El exilio de Zambrano en México y sus primeras colaboraciones", en Sánchez Cuervo, A.; Sánchez Andrés, A.; Sánchez Díaz, G. (coords.), María Zambrano: pensamiento y exilio, Morelia, Michoacán, UMSNH, Instituto de Investigaciones Históricas / Comunidad de Madrid, Consejería de Cultura y Deportes, p. 87. Con todo, hay otros intelectuales que coinciden con la argumentación de Francisco J. Martín, como es el caso de Octavio Paz: "Hubo según parece cierta oposición entre algunos de sus colegas (¡Una mujer profesora de Filosofía!) y se decidió enviarla a Morelia. Sin apenas darle tiempo a descansar y a conocer un poco la ciudad, con aquella indiferencia frente a la sensibilidad ajena que era uno de los rasgos menos simpáticos de su carácter, Cosío Villegas la despachó inmediatamente a Morelia. La ciudad es encantadora, pero María se sintió perdida, lejos de sus amigos y en un mundo ajeno a sus preocupaciones", "Una voz que venía de lejos (María Zambrano, 1904-1991)”, en Valender, J. et al., Homenaje a María Zambrano, México, El Colegio de México, 1988, pp. 23-24.

${ }^{25}$ La obra fue publicada por primera vez en el Fondo de Cultura Económica para "La Casa de Espańa" en Ciudad de México, resultado de tres conferencias impartidas por Zambrano en el Palacio de Bellas Artes de esta ciudad en junio de 1939. Valga aquí el propio relato de la autora: "Quisiera decir que la presente edición publicada en el Fondo de Cultura Económica para 'La Casa de Espańa', septiembre, 1939, corresponde a tres conferencias leídas, y a ratos dictadas, como miembro de 'La Casa de España' en la ciudad de México, siendo yo profesora en Morelia (Michoacán). Tiene, pues, un estilo oral, aunque no por timidez las leyera. Corresponde a un momento decisivo de mi vida: nada más terminada la guerra de Espańa, en México encontré no sólo la acogida, que México dio a tantos refugiados, sino una más inapreciable todavía, la de encontrar manera y lugar apropiados para mi pensamiento", Zambrano, M., "Nota aclaratoria a la presente edición espańola" - al frente de la edición de Endymion, año 1986-, recogida en Zambrano, M., Pensamiento y poesía en la vida española, en Obras Completas. I (Libros 1930-1939), edición de Jesús Moreno Sanz, Barcelona, Galaxia Gutenberg, 2013, p. 555.

26 Publicada en Morelia en ese trágico 1939, se podría ver como complemento de su obra Pensamiento y poesía en la vida española. "En este libro se perfilan con admirable lucidez las dos figuras en las que vendría a tomar cuerpo la humana, y por ello irrenunciable, vocación de la palabra: la del poeta y la del filósofo", Rodríguez, M., "Presentación" a Zambrano, M., Filosofia y poesía, en Obras Completas. I (Libros 1930-1939), op. cit., 2013, pp. 659-675. 
Emilio Prados, y de otros españoles exiliados con los que allí entabló amistad, y del intelectual mexicano Octavio Paz, a quien conoció en Valencia, en 1937, en el II Congreso Internacional de Escritores para la Defensa de la Cultura. Sea como fuere, el destino de Zambrano estaba otra vez abocado a la incertidumbre y forzado a adaptarse a personas y paisajes desconocidos. De nuevo fue Daniel Cosío Villegas, secretario de La Casa de España, quien movió hilos y pudo ayudar a la pensadora malagueńa en este segundo traslado, gracias a un acuerdo establecido con el rector de la Universidad Michoacana de San Nicolás de Hidalgo, Natalio Vázquez Pallares, para que entre los futuros profesores contratados estuviera María Zambrano ${ }^{27}$.

En la primavera de ese no tan floreado año 1939 llegó María Zambrano, en ferrocarril, a Morelia, en compañía de su marido. Bajo una serie de términos se desarrolló la docencia de la joven filósofa, quien, contratada como profesora residente en la Universidad Michoacana, impartió, siguiendo el plan de estudios propuesto por dicha institución, un curso de Introducción a la Filosofía - que comprendía las materias de Ética y Lógica- y otros de Sociología y Psicología. Al final de su vida, en su escrito "Entre violetas y volcanes", evocaba la grata impresión que la ciudad mexicana le causó en esos primeros días:

Ya profesora de Filosofía, como lo era en España, comencé a impartir clases -el mismo día que cayó Madrid en manos de los autollamados salvados- en la Universidad de Morelia, una Universidad que tenía, como toda la ciudad, el color de Salamanca, dorada. Se alzaban dos inmensas buganvillas que yo nunca había visto tan inmensas, esas dos torres de la catedral hecha por españoles, pero con manos indígenas, estaban rodeadas hasta arriba de buganvillas. Comencé a dar mi clase en medio de ese silencio, en ese que tiene el indito, y lo digo con todo cariño, en ese silencio del indito mexicano. Y cómo me escucharon, cómo me arroparon. Su silencio fue para mí como un encaje, como una envoltura o una mantilla de esas que les ponen a los niños que tiemblan. Porque yo temblaba por todo y me quitaron el temblar ${ }^{28}$.

\footnotetext{
27 "De acuerdo con las conversaciones que mi compañero de Patronato, el Dr. Arregui, celebró con usted en Morelia hace algo más de dos semanas, [y] con la conversación que los tres sostuvimos en mi oficina hace unos días, quisiera formalizar la sugestión que ha hecho el Patronato de La casa de España para que la universidad a su digno cargo acoja a tres profesores universitarios espańoles de los muchos que como consecuencia del desenlace de la guerra civil en Espańa se han dirigido al Patronato en demanda urgente de ayuda, aprovechando la ocasión casi única de asegurarse en condiciones excepcionales los servicios de profesores de primero orden”. Carta de Cosío Villegas a Vázquez Pallares, fechada el 21 de marzo de 1939, en Ciudad de México, en AHCOLMEX, Fondo Antiguo, caja 26, Correspondencia institucional y documentos de trabajo, carpeta 17, exp. María Zambrano. Cfr. Morán Gotari, B. y Sánchez Andrés, A., "El exilio de Zambrano en México y sus primeras colaboraciones”, en Sánchez Cuervo, A.; Sánchez Andrés, A.; Sánchez Díaz, G. (coords.), María Zambrano: pensamiento y exilio, Morelia, Michoacán, UMSNH, Instituto de Investigaciones Históricas/Comunidad de Madrid, Consejería de Cultura y Deportes, p. 88.

${ }_{28}$ Zambrano, M., “Entre violetas y volcanes”, en Las palabras del regreso, op. cit., p. 225.
} 
Contrariamente a lo que podría esperarse, dado que su vida académica quedó sometida en parte, durante este periodo, a los dictados ideológicos y políticos de la Universidad Michoacana ${ }^{29}$, y, en especial, a las sesgadas reformas educativas de su rector $^{30}$, el pensamiento de Zambrano continuó fluyendo libremente y su escritura filosófica fue fructífera. Allí escribió, junto a las dos obras capitales mencionadas, "Nietzsche o la soledad enamorada", que fue su primera publicación en Morelia, en el número 16, del mes de julio, de la revista Universidad Michoacana. Terminó su ensayo "San Juan de la Cruz. De la noche oscura en la más clara mística", texto que empezó a escribir en Barcelona, en 1938, y que vio la luz en diciembre de 1939 en la conocida revista argentina Sur - formada al calor de las vanguardias americanas, en 1931, y dirigida por Victoria Ocampo ${ }^{31}$ - y dos escritos que fueron publicados en la revista Taller, bajo la dirección de Octavio Paz: "Poesía y Filosofía" - un breve escrito introductorio a las ideas planteadas en su libro, que finalizará y publicará ese mismo año, Filosofia y poesia - y "Descartes y Husserl". Por otro lado, entre los proyectos de libros, que durante ese tiempo estaba preparando, destacaron los siguientes títulos: Miguel de Unamuno y su obra; Filosofía, poesía y tragedia; Breve historia de la mujer (La mujer, la sociedad y el Estado); El estoicismo como fenómeno de la crisis histórica, y los citados Pensamiento y poesía en la vida española y La crisis de la objetividad. De éstos, sólo se publicó en México, como se ha mencionado, Pensamiento y poesía; el resto de escritos formó parte, con posterioridad, de otras obras. Y, junto a estos libros-proyectos que no pudieron ser publicados, redactó Zambrano un buen número de bocetos de ensayos para cursos y conferencias: "La pasión y la imaginación", "El amor y el odio", "Los sentimientos sociales y los sentimientos morales", "Los sentimientos estéticos", entre otros dedicados al tema de las pasiones humanas ${ }^{32}$. Relevantes también resultan

\footnotetext{
${ }_{29}$ Puede consultarse el siguiente estudio de Raúl Arreola Cortés: Historia de la Universidad Michoacana, Morelia, Universidad Michoacana, 1984.

${ }^{30}$ Zambrano debía ajustarse al artículo 3 de la Constitución, la cual prescribía la educación socialista y, por ello, prescindir de la libertad de cátedra. Este mandato le fue informado por el rector de la Universidad Michoacana. En la actualidad, el hispanista Anthony Stanton ha reproducido algunas cartas de Zambrano dirigidas a Cosío Villegas donde le narra lo sucedido, vid.: “Alfonso Reyes y María Zambrano: una relación epistolar”, en Valender, J. et al., op. cit., p. 109.

31 La revista bonaerense Sur ya reflejó en su primer número sus intereses estéticos. Se centró en el redescubrimiento y exploración del continente americano, ayudó a difundir los movimientos artísticos y literarios del momento y, por encima de todo, la revista se posicionó ideológicamente, señala la investigadora Magali Fernández, mostrando su preocupación "con respecto a la mujer y su papel en la sociedad" (El discurso narrativo en la obra de María Luisa Bombal, Madrid, Pliegos, 1988, p. 21), de ahí el gran número de textos publicados en ella de escritoras y pensadoras, tanto europeas como americanas, del siglo XX, entre las cuales destacó María Zambrano. Véase el estudio de King, J., Sur. Estudio de la revista argentina y de su papel en el desarrollo de una cultura (1931-1970), México, Fondo de Cultura Económica, 1989.

32 Importante, en este sentido, el artículo que sobre el periodo universitario de Zambrano en Morelia realiza el investigador Gerardo Sánchez Diego titulado "Un exilio fecundo: María Zambrano en la Universidad Michoa-
} 
ser los temarios elaborados para los cursos de Filosofía que impartió en la Universidad Michoacana, pues reflejan el interés de la filósofa española por ciertos autores e ideas filosóficas. Incluso antes de finalizar el año dio por concluida una disertación sobre Filosofía y cristianismo, que fue publicada en la Editorial Losada, en Buenos Aires, y un estudio sobre Séneca, con el título Séneca y la resignación, que apareció más tarde, en 1944, también en Losada, como El pensamiento vivo de Séneca.

Mas, como se ha indicado, el hecho revelador durante este 1939 mexicano se daría con la publicación en paralelo de Filosofía y poesía y Pensamiento y poesía en la vida española. La primera: punto de partida al tema cumbre y clave de todo su pensamiento: la reconciliación entre la intuición poética y la razón filosófica. El conflicto eterno entre filosofía y poesía, que ya le alumbraron Antonio Machado y las lecturas del pensador danés Sören Kierkegaard, así como Miguel de Unamuno y Nietzsche, continuará presente en la mayoría de escritos posteriores, con gran entusiasmo y detalle en El hombre y lo divino $(1955 ; 1973)$, y, por supuesto, en Claros del bosque (1977), por citar sólo dos. En cuanto a la segunda obra, Pensamiento y poesía en la vida española, es, como es sabido, una meditación sobre la crisis de España, que se torna su propia crisis personal, su honda tragedia, al tiempo que trata sobre la crisis europea de la razón moderna, sistemática, que, en el parecer de Zambrano, es posible superar a través del conocimiento poético, conocimiento característico del pensamiento español. Además, ello justificaría el carácter confesional del texto, como explica la profesora e investigadora Mercedes Gómez Blesa, la simbiosis entre vida y pensamiento y la asistematicidad y la ausencia de método ${ }^{33}$.

El continuo contacto de la pensadora con miembros activos de La Casa de España, en especial, con Alfonso Reyes y Daniel Cosío, y las escapadas del matrimonio español a la capital hacían de México un lugar no tan aislado, y suponían la oportunidad para conseguir libros y revistas que Zambrano no encontraba en Morelia para preparar sus clases y profundizar en sus escritos filosóficos. Pese a sus intentos de acomodo, Morelia parecía no ser su ciudad, tal vez por el aislamiento intelectual en que se vio y por la escasez de recursos que halló en la Universidad: "la pobreza absoluta de medios en que nos encontramos", llegó a decir María Zambrano, por carta, a su amigo Reyes ${ }^{34}$. Y por ese mismo tiempo le confesó a otro buen amigo, Emilio Prados: "Quiero irme. Lo necesito. He pensado mucho en escribirte, pero la

cana”, en Sánchez Cuervo, A.; Sánchez Andrés, A.; Sánchez Díaz, G. (coords.), María Zambrano: pensamiento $y$ exilio, op. cit., pp. 111-124.

33 Véase: Gómez Blesa, M., "Presentación”, en Zambrano, M., Pensamiento y poesía en la vida española, en Obras Completas. I (Libros 1930-1939), op. cit., p. 532.

34 De nuevo, se hace necesario consultar el texto de Anthony Stanton "Alfonso Reyes y María Zambrano: una relación epistolar”, en Valender, J. et al., Homenaje a María Zambrano, op. cit., p. 119. Nota: carta fechada el 22 de agosto de 1939. 
angustia no me dejaba. [...] Quiero irme donde no haya tanto 'sabio' y sus mujeres que le roan a uno los huesos..." ${ }^{35}$. Su decepción fue clara, también para su esposo, lo cual les planteó a ambos la posibilidad de no permanecer más en esta tierra. México había cambiado para Zambrano, como luego recordaría:

Yo pasé unos momentos difíciles. Perdonen que diga yo, que me remita a mi experiencia. Momentos difíciles, no sólo por el terrible trasplante o la dureza del exilio. Porque en México resultaba especialmente duro, porque era en cierto modo Espańa, otro modo de ser España. Se sentía uno ser español, como si el ser espańol fuera un inmenso órgano con varios registros y uno de los registros o quizá el órgano principal era precisamente México, era una cuestión musical de trasponerse el ser español que ya no se podía, de trasponerlo al México que se nos ofrecía ${ }^{36}$.

En cualquier caso, este traspase se agotó, se acabó la estancia en Morelia. Sin embargo, otro mejor horizonte apareció frente a ella: Cuba, con su luz, su fuego secreto.

\section{La isla secreta}

MARÍA Zambrano ARRIBÓ - para quedarse, aunque no fue ésa su intención-a la isla antillana el 1 de enero de 1940, cuando fue invitada, por el Instituto de Altos Estudios e Investigaciones Científicas de La Habana, en iniciativa de José Lezama $\mathrm{Lima}^{37}$, a dar un ciclo de conferencias, siendo aún profesora en la Universidad Michoacana. La filósofa volvió a sentir Cuba íntima y cercana, semejante a esa primera vez, en el verano de 1936, en que creyó verse, de niña, en su Andalucía natal:

Veo que dejé raíces en La Habana donde yo me quedé por sentirlas muy en lo hondo de mí misma. En aquel domingo de mi llegada en que le conocí, la sentí recordándomela, creía volver a Málaga con mi padre joven vestido de blanco - de alpaca- y yo niña en un coche de caballos. Algo en el aire, en las sombras de los árboles, en el rumor del mar, en la brisa, en la sonrisa y en su misterio familiar. Y siempre pensé que al haber sido arrancada tan pronto de Andalucía tenía que darme el destino esa compensación de vivir en La Habana tanto tiempo, pues que las horas de la infancia son más lentas. Y ha sido así. En La Habana recobré mis sentidos de nińa, y la cercanía del misterio, y esos sentires que eran al par del destierro y de

\footnotetext{
35 Nota manuscrita de María Zambrano a Emilio Prados, anexa a la carta que le escribe su marido al poeta, desde Morelia, el 10 de julio de 1939. Se encuentra reproducida en: Chica, F., "Un cielo sin reposo. Emilio Prados y María Zambrano: correspondencia(s)”, en Valender, J. et al., op. cit., p. 203.

${ }^{36}$ Zambrano, M., "Entre violetas y volcanes", en Las palabras del regreso, op. cit., pp. 225-226.

${ }^{37}$ Véase la carta de José Lezama Lima a María Zambrano, sin fecha, reproducida en González Cruz, I. (ed.), Archivo de José Lezama Lima, Madrid, Centro de Estudios Ramón Areces, 1998, p. 600.
} 
la infancia, pues todo niño se siente desterrado. Y por eso quise sentir mi destierro allí donde se me ha confundido con mi infancia ${ }^{38}$.

En esta ocasión Cuba le ofrecía un presente y un futuro, además de un pasado común - histórico y cultural- con España, que parecía estar aún vigente, sobre todo por la labor dejada en el país por intelectuales españoles, como Federico García Lorca, Juan Ramón Jiménez o Manuel Altolaguirre ${ }^{39}$-quien fundó la imprenta La Verónica, y en ella, a partir de octubre de 1939, nació la revista Nuestra España, primera publicación de los exiliados españoles en América-. Sin embargo, la principal limitación del país caribeño fue la situación económica. Justo en 1940, María Zambrano, ante la inestable situación laboral, se dedicó a dictar cursos y conferencias breves - también en Puerto Rico ${ }^{40}$-, invitada por importantes centros culturales cubanos y por la Universidad (el Aula Magna de la Universidad de La Habana, y, en especial, su Escuela de Verano; la Sociedad de Estudios Filosóficos; el Ateneo de La Habana, la Universidad del Aire, entre otras). En concreto, en la Institución Hispanocubana de Cultura, fundada y dirigida por el historiador Fernando Ortiz ${ }^{41}$, donde participaron también, unos años atrás, Juan Ramón Jiménez y Federico García Lorca, dictó en el mes de marzo de 1940 cuatro conferencias dedicadas a "La mujer y sus formas de expresión en Occidente": "La mujer en la cultura medioeval, 1 y 2", "La mujer en el Renacimiento" y "La mujer en el Romanticismo", las cuales aparecieron en la revista Ultra ${ }^{42}$. Publicó ese mismo año de su llegada dos ensayos más, impresos en La Verónica, que gozaron de gran aceptación: "El freudismo, testimonio del hombre actual" e "Isla de Puerto Rico, nostalgia y esperanza de un mundo mejor", y empezó a colaborar en las revistas: Origenes, Espuela de Plata, Poeta, Ciclón, Bohemia, Carteles, Lyceum y Universidad de La Habana. Ese mismo mes habló sobre el pensamiento de su maestro Ortega y Gasset en el Ateneo de La Habana, en un ciclo, "Figuras de la filosofía contemporánea”, organizado por la Sección de Estudios Filosóficos, en el que partici-

\footnotetext{
${ }^{38}$ Carta de María Zambrano a José Lezama Lima, desde Roma, 1 de enero de 1956. Reproducida por Jorge Luis Arcos en Zambrano, M., La Cuba secreta y otros ensayos, edición e introducción de Jorge Luis Arcos, Madrid, Endymion, 1996, pp. 207-208. También puede consultarse el escrito "Breve testimonio de un encuentro inacabable", en Lezama Lima, José, Paradiso, edición crítica de Cintio Vitier, Madrid, Unesco, 1988, p. XV.

39 Cuadriello, J. D., Españoles en Cuba en el siglo XX, Sevilla, Renacimiento, 2004.

${ }^{40}$ Léase: Avilés-Ortiz, I. A., "María Zambrano en la isla de Puerto Rico: crónica de una estancia particular", en Aurora, Barcelona, n. 17 (2016), pp. 6-19.

${ }^{41}$ Toro González, C. del, Fernando Ortiz y la Hispanocubana de Cultura, La Habana, Fundación Fernando Ortiz, 1996.

${ }^{42}$ Revista difundida por la propia Institución Hispanocubana de Cultura. Las referencias bibliográficas de los textos mencionados son: Zambrano, M., "La mujer en la cultura medioeval, 1 y 2", Ultra, La Habana, vol. 8, núm. 45, 1940, pp. 274-278; "La mujer en el Renacimiento", Ibid., pp. 367-368, y "La mujer en el Romanticismo", Ibid., pp. 368-369.
} 
paron los filósofos José Ferrater Mora, Jorge Mañach, Medardo Vitier - presidente de dicha Sección-, y otros intelectuales de la época. Igualmente, presentó Zambrano, por esos meses, varias conferencias bajo el título "Tres momentos de la crisis histórica”, en el Aula Magna de la Universidad de La Habana ${ }^{43}$, y un curso sobre ética griega ("Los orígenes de la Ética"), en la Escuela libre de La Habana, creada por un grupo de exiliados españoles e intelectuales cubanos, compuesto de varias ponencias ${ }^{44}$.

Lentamente la vida se le fue abriendo: el misterio de la realidad, la belleza y la candidez de la niñez, las amistades, la irrupción de lo poético, las nuevas ideas. Unos años después, en el texto "Las catacumbas", publicado en 1943 en Revista de La Habana, y profundizando en el significado de éstas expresado en una carta al escritor cubano Virgilio Piñera, en 1941, describe María Zambrano Cuba, después de su partida de la "negra y densa tiniebla" que es Europa, como una catacumba a la manera de los antiguos cristianos, es decir, como un lugar que descifrar y del cual resucitar. Y continuando con su verdadera preocupación, unir vida y pensamiento, encontró en la isla, gracias a sus amigos poetas, "la única comunicación que parece efectuarse", que es, y precisa la pensadora en el mismo escrito:

Esta que realiza el presentimiento, emparentada tan cerca con lo que algunos místicos han llamado 'ver con el corazón'. Ver con el corazón, sentir lo que no está delante, habitar con el sentimiento allí donde no se está, participar en la vida misteriosa, oculta, en la vida entrañable $[\ldots]^{45}$.

Frente a la crisis espiritual, social, política - tiempo de orfandad - en que estaban sumidas Espańa y Europa, y, con ellas, Occidente, en la primera mitad del siglo xx, La Habana reaparecerá como lugar propio para la pensadora española, lugar donde lo mágico-religioso se funde con la realidad y el sueño con la vigilia, tal y como le revela la pintura del artista cubano, amigo, Wifredo Lam. Zambrano renació -y regresamos, de alguna manera, al comienzo de este capítulo, a su saber de iniciación-

\footnotetext{
43 En el Archivo de la Fundación María Zambrano, en la Caja 1, Carp. 10, se conservan las dos últimas partes del texto original dictado por Zambrano en este ciclo de conferencias: "Segundo momento: desconfianza y método" y "Tercer momento: la impotencia humana”, vid.: Dosil Mancilla, F. J., "El exilio en Cuba de María Zambrano”, en Sánchez Cuervo, A.; Sánchez Andrés, A.; Sánchez Díaz, G. (coords.), María Zambrano: pensamiento y exilio, op. cit., p. 134.

${ }^{44}$ Zambrano rechazó, finalmente, una de ellas, sobre el pensamiento de Ortega, debido a la ambigüedad política del filósofo español. En una carta escrita a Chacón, el 4 de marzo de 1949, en La Habana, dice así: "Ha llegado a mí la posición franquista de Ortega y ya es algo muy por encima de mis fuerzas el hablar sobre él. No me lo imagino. [...] Mi primera conferencia iba a ser esto precisamente: 'Ortega, figura de la vida y el pensamiento español' y su figura se me desdibuja y se me rompe... Quizá cuando pase algún tiempo me sea posible el componerla de nuevo, pero hoy se me ha hecho polvo y no quiero tampoco, en modo alguno, que se me trasluzca". La carta se encuentra reproducida en Zambrano, M., La Cuba secreta y otros ensayos, op. cit., p. 256.

45 Zambrano, M., "Las catacumbas”, en La Cuba secreta y otros ensayos, op. cit., p. 90.
} 
en la "islita" - como la llamaba carińosamente-. En ella comenzó a vivir de nuevo y a entrar, rememorando a su admirado San Juan de la Cruz y su "Noche obscura", "más adentro en la espesura", como en una catacumba, descendiendo muy abajo para luego volver a salir a la luz, trascender desde la más honda oscuridad. La "Cuba secreta”, que da nombre a uno de los ensayos más célebres de esta etapa, de 1948, llena de luz y sonidos - voces, danzas, música一, pero, del mismo modo, silenciosa y subterránea, oculta y misteriosa, se volverá carnal y amorosa presencia para la vida y la creación; además de espacio pre-natal y recóndito secreto:

Como un secreto de un viejísimo, ancestral amor, me hirió Cuba con su presencia en fecha ya un poco alejada. Amor tan primitivo que aun más que amor convendría llamar "apego". Carnal apego, temperatura, peso, correspondiente a la más íntima resistencia, respuesta física y por tanto sagrada, a una sed largo tiempo contenida. No la imagen, no la viviente abstracción de la palma y su contorno, ni el modo de estar en el espacio de las personas y las cosas sino su sombra, su peso secreto, su cifra de realidad, fue lo que me hizo creer recordar que la había ya vivido ${ }^{46}$.

La dramática vivencia del exilio se le volvió, en esta ínsula secreta, camino de aprendizaje - son muchos los textos que escribió, la mayoría recopilados por el investigador cubano Jorge Luis Arcos, en La Cuba secreta y otros ensayos—y posibilidad de creación de una nueva vida para Zambrano - la "Incipit vita nova" de Dante Alighieri a la que alude en Claros del bosque (1977)-, es decir, camino de libertad -libertad de pensar- y espacio de autoafirmación: recordemos la palabra Adsum que da comienzo a su obra Delirio y destino. Los veinte años de una española, "estoy aquî", escrita en Cuba en 1952. Un movimiento, pues, el suyo, de ascenso ("hay que subir siempre" 47 , llegó a decir la pensadora); una vida marcada profundamente por la historia sacrificial y a la conquista de una historia trascendente, buscando "la liberación humana de la pesadilla histórica y su permanente sacrificio, y la posibilidad de abrir tiempos en que fuese posible realmente la libertad" ${ }^{48}$, esto es, vivir el propio destino:

como realización, como cumplimiento de la promesa que anida en el fondo del ser humano y de su historia. La libertad no es otra cosa que la transformación del destino fatal y ciego en cumplimiento, en realización llena de sentido. Y la esperanza es el motor agente de esta transformación ascensional ${ }^{49}$.

\footnotetext{
46 Zambrano, M., "La Cuba secreta", en La Cuba secreta y otros ensayos, op. cit., p. 107.

47 Zambrano, M., "Amo mi exilio”, en Las palabras del regreso, op. cit., p. 65. Texto escrito en el ańo 1989.

${ }^{48}$ Moreno Sanz, J., "La política desde su envés histórico-vital: historia trágica de la esperanza y sus utopías", en Zambrano, M., Horizonte del liberalismo, Madrid, Morata, 1996, p. 152.

49 Zambrano, M., Los bienaventurados, Madrid, Siruela, 2004, p. 109. Libro escrito al final de su vida, en 1990.
} 


\section{A modo de epílogo}

ESE IR HACIA AMÉRICA reforzó un fuerte compromiso ético y crítico-hermenéutico y, en el campo intelectual, una relación muy estrecha con la tradición humanista hispánica. La filósofa, aunque lejos de su tierra de nacimiento, no olvidó ser representación de "una España que encontraba sus raíces en las viejas tradiciones liberales y progresistas de épocas pasadas" ${ }^{50}$, identificación en clara oposición con la idea de España elaborada por el franquismo. Bajo la decepción del proyecto civilizador de Europa, fuera de ese contexto sepultado por el totalitarismo y la barbarie, y ante la crisis del logos occidental, su conciencia de exiliada le llevó a proyectar un espíritu cosmopolita e integrador, no olvidando las propias tradiciones de pensamiento en lengua espańola que la hicieron nacer como pensadora y como persona, sino amalgamándolas con ésas que empezaban a fusionarse desde la otra orilla. Junto a la idea de España surgió la idea de América y con ellas un engrandecimiento del punto de vista. La cultura espańola se ensanchó, gracias a los exiliados, hasta el otro hemisferio, su historia no se escribía en singular, sino en plural, con el otro. Emisión y receptividad se entretejieron haciendo de la fraternidad y la solidaridad el arco de entrada hacia el nacer de otros sentidos o modos de ver. A su vez:

El fracaso definitivo de la modernidad dominante activa el rescate de una modernidad supuestamente dominada como la iberoamericana y en la que la conciencia exiliada proyecta - con una inevitable tendencia a la idealización en algunos momentos- su propia supervivencia. Se tantea así la vigencia de una tradición capaz de aportar luz al presente, de interrumpir su violencia e incluso de contribuir decisivamente a la realización de ese mismo programa moderno que la frustración europea ha dejado pendiente ${ }^{51}$.

Ante el grave desconcierto propiciado por las calamidades de la guerra española y el desalentador marco dibujado por Europa, otra vez acosada por espantosos conflictos bélicos, a Zambrano le salvó el sueño de construir un mundo humano habitable, digno de ser pensado y amado. Su exilio le posibilitó, decíamos, "un saber de iniciación", el acceso a un cosmos, la concesión de un nuevo orden, que dará lugar a una escritura inventora, descubridora, cuestionadora de la realidad, gestada desde lo profundo. Suerte que el sueño de su razón en el exilio no produjese monstruos

\footnotetext{
${ }^{50}$ López Sánchez, J. M., "El exilio de la Nueva España. Reflexiones sobre la españolidad republicana en México", en Cabañas, M.; Fernández, D.; Haro, N. de; Murga, I. (coords.), Analogías en el arte, la literatura y el pensamiento del exilio español de 1939, Madrid, Instituto de Historia. Consejo Superior de Investigaciones Científicas, 2010, pp. 327-328.

51 Sánchez Cuervo, A., “¿Pensamiento crítico en español? De la dominación al exilio”, en ARBOR. Ciencia, Pensamiento y Cultura, CLXXXIV 734 (2008), pp. 1018-1019.
} 
-aunque sí delirios, inacabables delirios- como los vaticinados por Goya, sino el surgimiento de instrumentos que hicieron factible que pudiera comprender y superar, como intelectual comprometida, la traumática y nebulosa existencia experimentada en sus propias entrańas, inducida por la crisis de su tiempo; crisis que, para Zambrano, resulta ser "lugar común" en su presente. En su libro Hacia un saber sobre el alma, publicado en 1950, nos lo afirma y explica:

No parece demasiado necesario justificar que creamos estar viviendo en crisis; es ya un lugar común de nuestros días, y como tantos lugares comunes nos hace correr el peligro de que resbalemos sobre él, sin adentrarnos. Mas, si sucede así será tanto como resbalar sobre nuestra propia vida. Y lo grave es que tal cosa: resbalar sobre la propia vida, sin adentrarse en ella, puede ocurrir con suma facilidad. Por eso es necesario que intentemos desentrañar lo que hay dentro de esta realidad a que aludimos al decir crisis. Es necesario. Y sin embargo, no podemos atrevernos a definirla de veras ${ }^{52}$.

Asimismo, es posible afirmar que su experiencia exilar, transformada en materia filosófica y poética, "se eleva", como sostiene la teórica Angelina Muñiz-Huberman pensando en el exilio como fenómeno en sí, "a expresiones cercanas a una experiencia de desprendimiento, casi místico" "53. En María Zambrano, en cierto modo, la mística se da como sinónimo de un encuentro con un universo propio y con una tradición de pensamiento, la española; también, podríamos pensar, como vía de escape a la irrupción de la barbarie y de los fascismos y los totalitarismos políticos que asolaban a Europa en las primeras décadas del siglo Xx, y, quizá con más acierto, diríase que su pensamiento místico está emparentado con el saber trágico, el único saber que, para Zambrano, "ha descubierto que la 'vida es sueño"" 54.

Sueño y tragedia conviviendo al unísono: saber de iniciación -(re)nacimiento, pregunta, apertura a toda posibilidad de ser- y descenso a los inferos, a los de la Historia y a los infiernos de la propia intimidad humana; estos últimos actuando como catarsis y como rechazo a la claridad de la razón moderna, cartesiana, "claridad que rechaza las tinieblas sin penetrar en ellas, sin deshacerlas en penumbra, sin abrir en ellas filos de luminosidad" 55 , al tiempo que anuncian "el umbral de una nueva época":

Un signo inequívoco de que estamos en el umbral de una nueva época, quizá de un nuevo mundo, es la necesidad y aun las parciales realizaciones de ese viaje que el hombre se ha visto

\footnotetext{
52 Zambrano, M., "La vida en crisis", en Hacia un saber sobre el alma, Madrid, Alianza Editorial, 2008, p. 99.

${ }_{53}$ Muñiz-Huberman, A., El canto del peregrino. Hacia una poética del exilio, Barcelona, Asociació d'Idees-GEXEL/ Universidad Nacional Autónoma de México, 1999, p. 175.

${ }^{44}$ Zambrano, M., Delirio y destino. Los cincuenta años de una española, Madrid, Horas y Horas, 2011, p. 22.

55 Zambrano, M., Notas de un método, Madrid, Mondadori, 1989, p. 25.
} 
siempre precisado a cumplir: el descenso a los infiernos, a sus propios infiernos. Infierno de la propia alma individual, infierno de la Historia poblada de ellos ${ }^{56}$.

Al verse obligada a abandonar su tierra, arrancadas quedaron sus raíces —atrás lo conocido y amado- y descentralizada quedó su mismidad. Quizá en algún momento, ante la dificultad de retornar a su país y ante la certeza de la derrota absoluta de la República, Zambrano sintió su alma como la de ese otro emigrado que se encuentra, como aclara el filósofo español Adolfo Sánchez Vázquez, "a hombros de una contradicción permanente: entre una aspiración a volver y la imposibilidad de realizarla" ${ }^{57}$. Y es esta situación bifronte la que llevaría a hablar, del mismo modo, de existencia trágica ${ }^{58}$. Desde un punto de vista epistemológico, sujeto puede significar persistencia, fundamento, solidez, pero también inestabilidad, cambio, vacío. El caso del sujeto exiliado es revelador por lo que tiene de aglutinador; él mismo puede amalgamar en sí ambos rostros tan opuestos. Ese extraño oxímoron ${ }^{59}$ puede deberse a su forzoso destino, que le exige vivir otra vida, es decir, ser otro imperativamente. Para José Ángel Ascunce Arrieta:

El exiliado se define por la 'otredad', una 'otredad' que no se relaciona con la realidad externa al sujeto sino con su propia realidad personal. Deja de ser uno mismo para asumir su otra identidad, personalidad impuesta, con otra historia y en un lugar diferentes a los suyos $\operatorname{propios}^{60}$.

Ese definirse en la 'otredad', esa alteración de sí mismo, es, en cierto modo, una forma de alienación —noción marxiana de Entfremdung- ${ }^{61}$, y, en tanto alienación,

56 Zambrano, M., "Un descenso a los infiernos", en Aurora. Papeles del "Seminario María Zambrano", Barcelona, n. 9 (2008), p. 83

57 Sánchez Vázquez, A., "Fin del exilio y exilio sin fin”, en Recuerdos y reflexiones del exilio, Barcelona, GEXEL, 1997 , p. 46.

58 En estos años su amigo Emil Cioran, a quien María Zambrano conoció en París, escribió su conocida obra De lágrimas y de santos (1932). En ella el joven escritor rumano se pregunta, reflexionando, esencialmente, sobre el sentido trágico de la historia, si no será que la existencia misma sea exilio.

59 Hacemos aquí uso del vocablo "oxímoron", no sólo en su valor tropológico de figura retórica, sino en su sentido semántico, en tanto que se trata de "la unión sintáctica íntima de conceptos contradictorios en una unidad, la cual queda con ello cargada de una fuerte tensión contradictoria”, Lausberg, H., Manual de retórica literaria. Fundamentos de una ciencia de la literatura, Madrid, Gredos, 1966, p. 222.

${ }^{60}$ Ascunce Arrieta, J. Á., "El exilio entre la experiencia subjetiva y el hecho cultural: tema para un debate", en Ascunce Arrieta, J. Á. (coord.), El exilio: debate para la historia y la cultura, San Sebastián, Ed. Saturrarán, 2008, p. 33 .

${ }^{61}$ Podemos emparentar estas nociones, la de “alteración” y la de "alienación”, con ésta que indica Javier Muguerza: “con la noción hegeliana de Entäusserung o 'enajenación', noción ésta que añade a la de alienación o 'extrañamiento' la de 'exteriorización', como en el caso del proceso a través del cual la idea o el ser en sí se exteriorizan para Hegel en el fuera de sí -o mundo de la 'otredad'- con el fin de cobrar de esa manera conciencia de sí y 
ese volverse otro se vive trágicamente, porque implica dejar de ser lo que se era para ser algo que, en principio, por hallarse indefinido, indeterminado, desconcierta de manera inexorable. Y pese a que las circunstancias son las que fuerzan a este sujeto a ser otro no son éstas las que dictan quién o cómo va a ser, sino su propia soledad. Con todo, Zambrano transformó esta tragedia, el exilio, en camino de perfección ${ }^{62}$, en privilegio, a pesar del dolor, a pesar de la nostalgia, a pesar de la injusticia: "Así que estoy entre dos mundos o entre dos Continentes; no soy la única y creo que se trata de una situación de privilegio desde el punto de vista moral e intelectual" 63 . Hizo del exilio histórico su exilio interior, metafísico, místico, metafórico, y tal vez por ello acabó amándolo; sentimiento que reconocería muchos años después, en su regreso definitivo a España:

Hay ciertos viajes de los que sólo a la vuelta se comienza a saber. Para mí, desde esa mirada del regreso, el exilio que me ha tocado vivir es esencial. [...]

Creo que el exilio es una dimensión esencial de la vida humana, pero al decirlo me quemo los labios, porque yo querría que no volviese a haber exiliados, sino que todos fueran seres humanos y a la par cósmicos, que no se conociera el exilio. Es una contradicción, qué le voy a hacer; amo mi exilio, será porque no lo busqué, porque no fui persiguiéndolo. No, lo acepté; y cuando se acepta algo de corazón, porque sí, cuesta mucho trabajo renunciar a ello ${ }^{64}$.

transformarse en idea o en ser para sî", Muguerza, J., "La herencia filosófica de La Casa de España en México: José Gaos y el pensamiento de lengua española”, en Anuario de Estudios Atlánticos, n. 59 (2013), p. 784.

${ }^{62}$ Como el protagonista de una de las obras capitales de Pío Baroja del mismo título (1902), Fernando Ossorio, quien, atormentado por las experiencias ligadas a la muerte, inicia un viaje, desde Madrid hasta Levante, necesario y purificador. Tanto que en ese camino afirma: "Debo ser un espíritu religioso. Por eso quizá no me he podido adaptar a la vida. Busquemos el descubrir lo que hay en el fondo del alma; debajo de las preocupaciones; debajo de los pensamientos; más allá del dominio de las ideas”, Baroja, P., Camino de perfección (pasión mística), Madrid, Alianza Editorial, 2004, p. 137.

${ }^{63}$ Carta de María Zambrano a su amiga cubana Josefina Tarafa, escrita en París, el 12 de marzo de 1951. Archivo de la Fundación María Zambrano.

${ }^{64}$ Zambrano, M., “Amo mi exilio”, Las palabras del regreso, op. cit., p. 66. 


\section{REFERENCIAS BibLIOGRÁficAS}

Abellán, J. L., El exilio filosófico en América. Los transterrados de 1939, Madrid, Fondo de Cultura Económica, 1998.

Arreola Cortés, R., Historia de la Universidad Michoacana, Morelia, Universidad Michoacana, 1984.

Ascunce Arrieta, J. Á. (coord.), El exilio: debate para la historia y la cultura, San Sebastián, Ed. Saturrarán, 2008.

Avilés-Ortiz, I. A., "María Zambrano en la isla de Puerto Rico: crónica de una estancia particular", en Aurora, Barcelona, n. 17, 2016, pp. 6-19.

Baroja, P., Camino de perfección (pasión mistica), Madrid, Alianza Editorial, 2004.

Bergamín, J., Dolor y claridad de España. Cartas a María Zambrano, Sevilla, El Clavo Ardiendo. Editorial Renacimiento, 2004.

Bernárdez, M., "La metáfora del corazón", en Rivara, G. y Lizaola, J. (eds.), Exilio y razón poética. María Zambrano en el centenario de su nacimiento, México D.F., Cátedras. Universidad Nacional Autónoma de México, 2009, pp. 133-149.

Bernecker, W. L., "Los estudios sobre el exilio republicano en México", en Pagni, A. (ed.), El exilio republicano español en México y Argentina. Historia cultural, instituciones literarias, medios, Bilbao, Iberoamericana. Vervuert. Bonilla Artigas Editores, 2011, pp. 33-57. https://doi.org/10.31819/9783964562739-003

BundGÅRD, A., "El binomio España-Europa en el pensamiento de Zambrano, Ferrater Mora y Ortega y Gasset", en Revilla, C. (coord.), Claves de la Razón Poética. María Zambrano: un pensamiento en el orden del tiempo, Madrid, Trotta, 1998, pp. 43-54.

Bundgård, A., "Exilio y transcendencia", en Aurora. Papeles del "Seminario María Zambrano", Barcelona, n. 8, 2007, pp. 83-89.

Cuadriello, J. D., Españoles en Cuba en el siglo XX, Sevilla, Renacimiento, 2004.

Dosil Mancilla, F. J., "El exilio en Cuba de María Zambrano", en Sánchez Cuervo, A.; Sánchez Andrés, A.; Sánchez Díaz, G. (coords.), María Zambrano: pensamiento y exilio, Morelia, Michoacán, UMSNH, Instituto de Investigaciones Históricas / Comunidad de Madrid, Consejería de Cultura y Deportes, pp. 125-172. 
FERnÁndez, M., El discurso narrativo en la obra de María Luisa Bombal, Madrid, Pliegos, 1988.

González Cruz, I. (ed.), Archivo de José Lezama Lima, Madrid, Centro de Estudios Ramón Areces, 1998.

Hurtado, G., "La filosofía en México en el siglo XX”, en Garrido, M.; Orringer, N. R.; Valdés, L. de; Valdés, M. M. (coords.), El legado filosófico español e hispanoamericano del siglo XX, Madrid, Cátedra, 2009, pp. 1159-1173.

KING, J., Sur. Estudio de la revista argentina y de su papel en el desarrollo de una cultura (1931-1970), México, Fondo de Cultura Económica, 1989.

Lausberg, H., Manual de retórica literaria. Fundamentos de una ciencia de la literatura, Madrid, Gredos, 1966.

Lida, C. E., La Casa de España en México, México, El Colegio de México, 1988. https://doi.org/10.2307/j.ctv26d91p

LidA, C. E., "El exilio en vilo”, en Pagni, A. (ed.), El exilio republicano español en México y Argentina. Historia cultural, instituciones literarias, medios, Bilbao, Iberoamericana. Vervuert. Bonilla Artigas Editores, 2011, pp. 21-32.

Llera, L. de, Filosofía en el exilio: España redescubre América, Madrid, Ediciones Encuentro, 2004.

López Sánchez, J. M., "El exilio de la Nueva España. Reflexiones sobre la españolidad republicana en México”, en Cabañas, M.; Fernández, D.; Haro, N. de; Murga, I. (coords.), Analogias en el arte, la literatura y el pensamiento del exilio español de 1939, Madrid, Instituto de Historia. Consejo Superior de Investigaciones Científicas, 2010, pp. 327-340.

Morán Gotari, B. y Sánchez Andrés, A., "El exilio de Zambrano en México y sus primeras colaboraciones”, en Sánchez Cuervo, A.; Sánchez Andrés, A.; Sánchez Díaz, G. (coords.), María Zambrano: pensamiento y exilio, Morelia, Michoacán, UMSNH, Instituto de Investigaciones Históricas / Comunidad de Madrid, Consejería de Cultura y Deportes, pp. 81-94.

Moreno SAnz, J., "La política desde su envés histórico-vital: historia trágica de la esperanza y sus utopías", en Zambrano, M., Horizonte del liberalismo, Madrid, Morata, 1996, pp. 9-193.

Muguerza, J., "La herencia filosófica de La Casa de España en México: José Gaos y el pensamiento de lengua espańola”, en Anuario de Estudios Atlánticos, n. 59, 2013, pp. 769-789.

Muñiz-Huberman, A., El canto del peregrino. Hacia una poética del exilio, Barcelona, Asociació d'Idees-GEXEL/Universidad Nacional Autónoma de México, 1999. 
Pagni, A. (ed.), El exilio republicano español en México y Argentina. Historia cultural, instituciones literarias, medios, Bilbao, Iberoamericana. Vervuert. Bonilla Artigas Editores, 2011. https://doi.org/10.31819/9783964562739

Paz, O., Hombres en su siglo, Barcelona, Seix Barral, 1984.

Rodríguez, M., "Presentación”, en Zambrano, M., Filosofía y poesía, en Obras Completas. I (Libros 1930-1939), edición de Jesús Moreno Sanz, Barcelona, Galaxia Gutenberg, 2013., pp. 659-675.

SaId, E. W., Reflexiones sobre el exilio, Barcelona, Debate, 2001.

SÁnchez Cuervo, A., "¿Pensamiento crítico en español? De la dominación al exilio”, en ARBOR. Ciencia, Pensamiento y Cultura, CLXXXIV 734, 2008, pp. 1015-1024.

SÁnchez Diego, G., "Un exilio fecundo: María Zambrano en la Universidad Michoacana", en Sánchez Cuervo, A.; Sánchez Andrés, A.; Sánchez Díaz, G. (coords.), María Zambrano: pensamiento y exilio, Morelia, Michoacán, UMSNH, Instituto de Investigaciones Históricas / Comunidad de Madrid, Consejería de Cultura y Deportes, pp. 111-124.

SÁnchez VÁzquez, A., Recuerdos y reflexiones del exilio, Barcelona, GEXEL, 1997.

Soто, P., "Chile: un inolvidable y decisivo viaje”, en Moreno Sanz, J. y Muñoz Vitoria, F. (eds.), María Zambrano, 1904-1991. De la razón cívica a la razón poética, Madrid, Publicaciones de la Residencia de Estudiantes-Fundación María Zambrano, 2004, pp. 103-109.

Sото, P., "María Zambrano en Chile", en Moreno Sanz, J. (ed.), María Zambrano. Ahora, ya, monográfico de la revista República de las letras, Madrid, n. 89, 2005, pp. 48-68.

Tirado RozÚa, J. R., "La razón poética ante la democracia", en Actas del II Congreso Internacional sobre la vida y obra de María Zambrano, Fundación María Zambrano, Vélez-Málaga, v. I, 1998, pp. 785-798.

Toro González, C. del, Fernando Ortiz y la Hispanocubana de Cultura, La Habana, Fundación Fernando Ortiz, 1996.

VALDÉs, M. M., "El pensamiento filosófico en Hispanoamérica en el siglo XX", en Garrido, M.; Orringer, N. R.; Valdés, L. M.; Valdés, M. M. (coords.), El legado filosófico español e hispanoamericano del siglo XX, Madrid, Cátedra, 2009, pp. 1113-1127.

Valender, J. et al., Homenaje a María Zambrano, México, El Colegio de México, 1988. 
Vitoria, F. (eds.), María Zambrano, 1904-1991. De la razón cívica a la razón poética, Madrid, Publicaciones de la Residencia de Estudiantes-Fundación María Zambrano, 2004, pp. 103-109.

Zambrano, M., "La mujer en la cultura medioeval, 1 y 2", Ultra, La Habana, vol. 8, n. 45, 1940, pp. 274-278; "La mujer en el Renacimiento", Ibid., pp. 367368, y "La mujer en el Romanticismo", Ibid., pp. 368-369.

Zambrano, M., Notas de un método, Madrid, Mondadori, 1989.

Zambrano, M., "A modo de Prólogo", en Filosofía y poesía, México, Fondo de Cultura Económica, 1993, pp. 7-8.

Zambrano, M., Los bienaventurados, Madrid, Siruela, 2004.

Zambrano, M., El hombre y lo divino, Madrid, Fondo de Cultura Económica, 2005.

Zambrano, M., La Cuba secreta y otros ensayos, edición e introducción de Jorge Luis Arcos, Madrid, Endymion, 1996.

Zambrano, M., Hacia un saber sobre el alma, Madrid, Alianza Editorial, 2008.

Zambrano, M., España. Pensamiento, poesía y una ciudad, edición de Francisco José Martín, Madrid, Biblioteca Nueva, 2008.

Zambrano, M., "Un descenso a los infiernos", en Aurora. Papeles del "Seminario María Zambrano", Barcelona, n. 9, 2008, pp. 83-87, y n. monográfico "Documentos de María Zambrano", 2012, pp. 76-81.

Zambrano, M., Las palabras del regreso, edición de Mercedes Gómez Blesa, Madrid, Cátedra, 2009.

Zambrano, M., Delirio y destino. Los veinte años de una española, Madrid, Horas y Horas, 2011.

Zambrano, M., Pensamiento y poesía en la vida española, en Obras Completas. I (Libros 1930-1939), edición de Jesús Moreno Sanz, Barcelona, Galaxia Gutenberg, 2013.

ZeA, L., El positivismo en México, México, El Colegio de México, 2 tomos, 19431944 (nueva edición en México, Fondo de Cultura Económica, 1975).

DOI: https://doi.org/10.15366/bp2020.25.006

Bajo Palabra. II Época. No25. Pgs: 129-152 